\title{
DOI https://doi.org/10.30525/978-9934-26-179-4-33
}

\section{AGE OF A MINOR AND THE PRINCIPLE OF IRRESPONSIBILITY OF ADMINISTRATIVE RESPONSIBILITY}

\author{
Ratushenko O. M. \\ Judge \\ Sokyryany District Court of Chernivtsi Region \\ Chernivtsi, Ukraine
}

The implementation of the principle of inevitability of administrative responsibility of minors is associated with special protection of the interests of such a minor. Administrative responsibility of minors has constructive features. They are determined by the age of the person being held accountable. Applying such responsibility to a specific group of persons - minors who need special attention and care from society in the process of exercising their rights and freedoms. Moreover, this is the most important condition for their physical and mental development, ensuring their well-being. The inevitability of administrative liability depends to a greater extent on the proper functioning of law enforcement agencies, on the professionalism of employees authorized to prosecute and apply sanctions. Administrative misconduct, to which the state did not respond, causes serious damage to the rule of law. The offender's impunity encourages them to commit new offenses and sets a negative example for other vulnerable individuals.

The responsibility of minors can be investigated in various aspects. This may be under administrative law, and the problems and prospects of administrative influence applied to minors. The peculiarities of administrative measures applied to minors in Ukraine are also studied. Another area is administrative responsibility as a means of juvenile prevention. And in each such study, the principle of the inevitability of the application of administrative responsibility to such a specific group of subjects as minors cannot be ignored. Bringing minors to administrative responsibility is directly related to such a legal structure of administrative law as administrative legal personality, and in particular, its element - administrative tort. Administrative tort of the subject of legal relations is part of its administrative and legal status and is the ability of a person to bear legal responsibility for violating the rules of administrative tort law [1, p. 46].

The application of the principle of inevitability of administrative responsibility of minors is determined by the following limits. First, it is the age from which a person can be held administratively liable (it is defined in 
Article 12 of the Code of Ukraine on Administrative Offenses). Secondly, it is sanity, but despite the fact that Article 20 of the Code of Administrative Offenses of Ukraine defines the notion of insanity, but for us the priority is to study the issue of juvenile sanity in order to implement the principle of inevitability of administrative responsibility of such persons.

The age of a person, according to the Code of Ukraine on Administrative Offenses, is one of the defining requirements for bringing such a person to administrative responsibility. Article 12 of the Code of Ukraine on Administrative Offenses establishes that persons who have reached the age of sixteen at the time of committing an administrative offense are subject to administrative responsibility [2]. However, it is important to note that 16 years must be at the time of the offense (this time starts from the first minute of the day following the date of birth), and not at the time of the case. Therefore, persons under the age of 16 may not be the subject of an administrative offense.

The limit of application of the principle of inevitability is also important when considering administrative cases concerning minors. Because the age of the person in question is crucial. Particular attention should be paid to the fact that cases of administrative offenses committed by minors between the ages of sixteen and eighteen are heard by judges of district, city, city or city district courts. Such judicial bodies have the right to bring this category of subjects to administrative responsibility. Therefore, we can say that the administrative responsibility of minors is only judicial.

However, foreign experience is more constructive, because, for example, in Germany, bringing to administrative responsibility occurs from 14 years. This is due to the fact that a person at the time of the offense could be aware of the essence of his action by virtue of his sufficient mental and moral maturity [3]. In the USA, a minor who has reached the age of 14 is fully responsible for the act committed, because at that age he fully understands the «wrongness» of his act. In addition, for example, English law distinguishes three groups of minors, one of which also includes adolescents aged 14 years [4, p. 167-170]. Foreign experience in reducing the age of responsibility shows quite effective results, as it is based on the reality of the 14-year-old's understanding of the act and its consequences.

The inevitability of the administrative responsibility of a minor is also directly related to such a category as sanity - a mental state of a person when a person can be aware of his actions (inaction) and control them during the commission of a crime. According to Article 20 of the Code of Administrative Offenses of Ukraine, it is determined that a person who was in a state of insanity at the time of committing an illegal act or omission is not subject to administrative responsibility. That is, she could not be aware 
of or control her actions due to chronic mental illness, temporary mental disorder, dementia or other morbid conditions [2]. Therefore, the expertise of specialists in the field of child and youth psychology can be applied to such a person, or these issues can be asked by a psychiatrist. This is done to determine the general development of the minor, to determine the level of his mental retardation and to clarify the question - whether such a person could be fully aware of the importance of their own actions and to what extent to control them.

So, as a conclusion we can say that limit of application of the principle of inevitability is determined by three conditions: connection of the principle of inevitability of administrative responsibility of minors with the category of «administrative tort»; connection of the principle of inevitability of administrative responsibility of minors with the achievement and proper establishment of the age of a minor; connection of the principle of inevitability of administrative responsibility of minors on establishment of sanity of the person.

\section{References:}

1. Shul'ha, YE. V. Osoblyvosti pravosub"yektnosti osib v administratyvno-deliktnykh vidnosynakh. Mizhnarodnyy naukovyy zhurnal Internauka. Seriya: Yurydychni nauky. 2017. (3). 44-49.

2. Kodeks Ukrayiny pro administratyvni pravoporushennya: redaktsiya vid 26 zhovtnya 2017 roku, pidstava 2109-19. URL: http://zakon.rada.gov.ua/ laws/show/80731-10

3. Tripak YU.R., Krakovs'ka A.YE. Administratyvna vidpovidal'nist' nepovnolitnikh. Visnyk students'koho naukovoho tovarystva DonNU imeni Vasylya Stusa, 2019. 1(11), 23-28.

4. Pavlovs'ka A. A. Vik, z yakoho nastaye kryminal'na vidpovidal'nist' nepovnolitnikh (zarubizhnyy dosvid). Visnyk Asotsiatsiyi kryminal'noho prava Ukrayiny. 2016. № 1. S. 166-174. 